\title{
Benteng Rotterdam Berdasarkan Kajian Perkembangan Benteng Kolonial Di Indonesia
}

\section{Novida Abbas}

Keywords: defense, military, colonial, dutch, fortress, architecture

\section{How to Cite:}

Abbas, N. (2005). Benteng Rotterdam Berdasarkan Kajian Perkembangan Benteng Kolonial Di Indonesia. Berkala Arkeologi, 25(1), 46-52. https://doi.org/10.30883/jba.v25i1.909

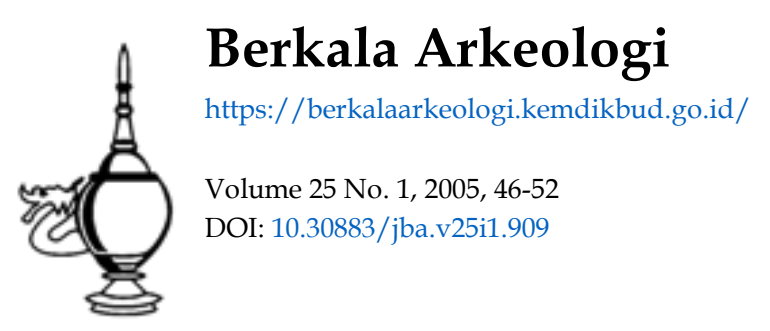

\section{(c) (i) (2)}

This work is licensed under a Creative Commons Attribution-NonCommercial-ShareAlike $\underline{4.0 \text { International License. }}$ 


\title{
BENTENG ROTTERDAM BERDASARKAN KAJIAN PERKEMBANGAN BENTENG KOLONIAL DI INDONESIA ${ }^{+}$
}

\author{
Oleh: Novida Abbas
}

\section{Sejarah dan Perkembangan Benteng Kolonial di Indonesia}

Kehadiran Belanda di Indonesia selama sekitar tiga setengah abad telah meninggalkan jejak-jejaknya, baik fisik maupun non-fisik. Tinggalan fisik dari masa itu di antaranya ada yang berupa benteng pertahanan, sebagai salah satu tinggalan arkeologi militer yang selama ini kurang mendapat perhatian dibandingkan dengan tinggalan fisik lainnya, padahal secara kuantitatif jumlah benteng pertahanan tersebut cukup banyak dan tersebar di berbagai wilayah di Indonesia. Dalam perjalanan sejarah Indonesia, benteng-benteng Belanda mempunyai peran penting bagi mereka dalam mempertahankan kedudukan dan kekuasaannya.

Kehadiran Belanda (dan bangsa Eropa lainnya) di Indonesia pada sekitar akhir abad XVI awalnya mempunyai motivasi ekonomi, yaitu perdagangan rempahrempah. Di abad-abad selanjutnya Belanda (utamanya) meletakkan dasar-dasar militer yang diperlukan untuk memperoleh hegemoni perdagangan dan secara bertahap mulai menganeksasi berbagai wilayah di Indonesia. Di awal abad XVII Belanda mulai mendirikan benteng-bentengnya yang pertama, dengan tujuan untuk memperoleh dan memiliki tempat yang aman dan terlindung, serta sekaligus untuk mencegah datangnya pedagang-pedagang bangsa Eropa lainnya. Menjelang akhir abad XVII lebih banyak benteng didirikan untuk menjamin keselamatan dan kelancaran perdagangan Belanda. Pada periode akhir, terutama di abad XVIII dan XIX benteng-benteng terutama didirikan untuk menghadapi pemberontakanpemberontakan yang muncul di berbagai tempat di Indonesia.

Sejumlah faktor mempengaruhi pemilihan lokasi pendirian benteng, di antaranya:

- Pentingnya suatu tempat bagi Belanda pada masa pendirian benteng (misalnya potensi tempat itu untuk dijadikan pusat perdagangan atau pelabuhan, adanya suplai produk yang dibutuhkan Belanda, dan potensi untuk digunakan sebagai pusat pemerintahan lokal).

- Ancaman atau penolakan yang dihadapi Belanda (misalnya ancaman eksternal dari pedagang bangsa asing lain dan ancaman internal dari penguasa setempat).

${ }^{+}$Pernah dipresentasikan dalam Sarasehan Benteng Rotterdam, Makassar 6 Desember 2004 
- Strategi yang diterapkan Belanda dalam upayanya menaklukkan suatu wilayah tertentu untuk perluasan kekuasaan mereka.

Sejarah perbentengan dapat dilacak sepanjang sejarah kehidupan manusia itu sendiri. Pada masa prasejarah manusia telah menyadari bahwa untuk dapat mempertahankan hidup, baik dari ancaman binatang buas, alam, maupun kelompok manusia lainnya, mereka harus berada di suatu posisi strategis yang memungkinkan mereka untuk melihat apabila ancaman datang dan sekaligus mempunyai cukup waktu untuk mempersiapkan langkah-langkah antisipasi (Hogg, 1975: 8). Ian V. Hogg (I975) mendefinisikan perbentengan atau benteng sebagai "serangkaian bangunan pertahanan untuk melindungi suatu area tertentu dan berada di bawah pimpinan satu orang".

Benteng-benteng Belanda di berbagai wilayah di Indonesia tidak seluruhnya didirikan oleh Belanda. Pada awal kedatangannya, Belanda cukup banyak memanfaatkan benteng-benteng yang telah didirikan sebelumnya oleh bangsa lain, misalnya Portugis. Di masa-masa selanjutnya, sesuai dengan perkembangan kebutuhan mereka, Belanda mulai mendirikan benteng-bentengnya sendiri di berbagai tempat. Pada masa-masa awal, benteng-benteng yang didirikan oleh Belanda umumnya berbentuk sederhana, dengan denah bulat, segi tiga, dan bujur sangkar atau persegi. Selanjutnya, mulai dibangun benteng-benteng dengan disain yang lebih rumit, seperti benteng-benteng dengan denah pentagonal dan oktagonal.

\section{Benteng Rotterdam dalam perkembangan perbentengan Belanda di Indonesia berdasarkan kajian arkeologi}

Kajian terhadap benteng-benteng Belanda di Indonesia sebagai objek arkeologi belum banyak dilakukan. Beberapa benteng Belanda di Sulawesi dan Nusatenggara Timur pernah diteliti oleh Belanda (Wall, 1930/1931). Setelah kemerdekaan sejumlah studi pernah dilakukan terhadap benteng-benteng Inggris dan Belanda di Sumatra (Tim Ditlinbinjarah, 1987/1988), Maluku (Tim Ditlinbinjarah, 1982/1983), Sulawesi (Sarjiyanto, 2002), dan Jawa (Hatmosuprobo, 1979; Abbas, 2001). Studi-studi tersebut sebagian besar tidak dilakukan secara spesifik, melainkan sebagai bagian dari studi yang lebih luas terhadap suatu daerah tertentu, atau studi kelayakan dalam kaitannya dengan pemugaran terhadap benteng itu sendiri. Sebagai contoh adalah studi yang dilakukan di Benteng Belgica, Bandaneira, Maluku (Tim Ditlinbinjarah, 1982/1983). Studi tersebut lebih ditekankan pada aspek disain Benteng Belgica dan dilakukan dalam menyiapkan master plan untuk pemugaran benteng itu. Contoh lain adalah studi terhadap Benteng Speelwijck di Banten oleh Pusat Penelitian Arkeologi Nasional dalam suatu proyek jangka panjang untuk mengungkapkan berbagai aspek yang terdapat di kota Banten (Mundarjito et al., 1978). Dari beberapa contoh di atas tampak bahwa kajian arkeologis terhadap 
benteng Belanda masih bersifat umum, dalam arti belum dilakukan sebagai bagian dari upaya untuk memperoleh pemahaman lebih lanjut atas situasi ekonomi dan sosial yang terjadi pada masa guna benteng tersebut.

Benteng Rotterdam di Makasar (gambar 1) merupakan salah satu benteng Belanda yang awalnya merupakan benteng lokal yang dinamakan Benteng Ujung Pandang dan telah ada sejak pertengahan abad XVI. Sejauh ini tampaknya kajian arkeologi secara menyeluruh belum pernah dilakukan terhadap Benteng Rotterdam, meskipun kajian dalam kaitannya dengan pemugaran tentunya sudah cukup banyak dilakukan. Namun demikian, tentunya masih banyak aspek yang dapat digali dari keberadaan Benteng Rotterdam ini, mengingat benteng ini digunakan oleh Belanda dalam kurun waktu yang cukup panjang dan aktivitas yang terjadi di dalam benteng itu pada masa gunanya cukup beragam.

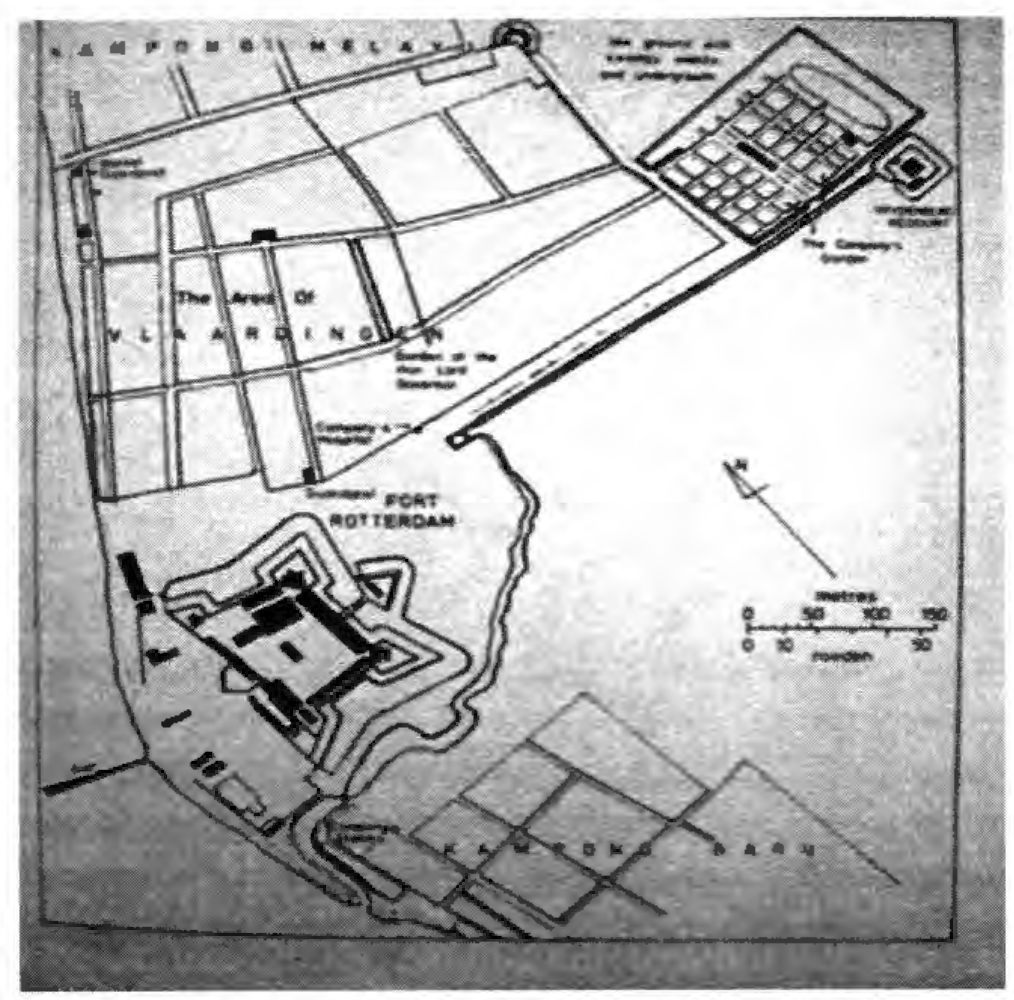

Gambar 1. Denah benteng Rotterdam

\section{Kajian arsitektural Benteng Rotterdam}

Sejak Perjanjian Bonggaya (1667), Benteng Ujung Pandang jatuh ke tangan Belanda dan kemudian dinamakan Benteng Rotterdam untuk menghormati tempat kelahiran Speelman (Stapel, 1922: 187-189; Andaya, 1981: 106). Benteng ini 
berlokasi di tempat yang strategis, yaitu di dekat pelabuhan di tepi Selat Makassar. Benteng ini dibangun oleh Belanda pada tahun 1669-1677, meskipun di tahuntahun sesudahnya masih terdapat penambahan sejumlah bangunan lagi di dalam benteng.

Dari peta yang berasal dari abad XVII dan dari deskripsi yang dilakukan oleh Belanda (Encyclopaedie van Nederlandsch-Indie 2e deel, 1918; Wall, 1930: 83128; 1942: 44-45) maupun Inggris (Thorn, 1993: 334) diketahui bahwa benteng Rotterdam memiliki bentuk dasar segi empat tidak beraturan (dengan luas $147.5 \mathrm{~m}$ x $125 \mathrm{~m}$ ) dan pada masing-masing sudutnya terdapat bastion. Pada sisi yang menghadap ke laut terdapat sebuah bastion di tengah, tempat meletakkan tiang bendera. Di luar pintu masuk yang menghadap ke darat terdapat semacam kubu pelindung (Bld. bolwerk, Ing. bullwark) yang berdenah setengah

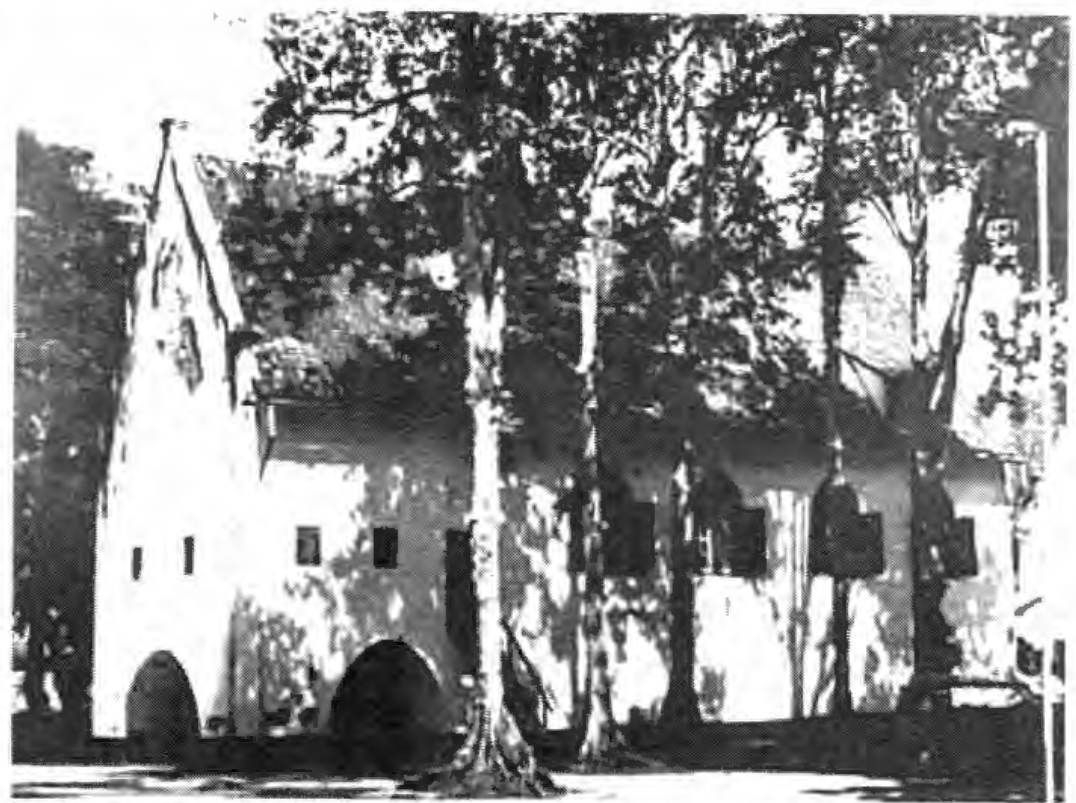

Gambar 2. Gereja di dalam benteng Rotterdam (Sumber: Atlas Mutual Heritage) lingkaran. Benteng ini dikelilingi parit pada ketiga sisinya, kecuali pada sisi yang menghadap ke laut. Di bagian dalam benteng terdapat sejumlah bangunan yang terdiri atas barak-barak prajurit, gudang senjata, gudang mesiu, gudang logistik, gereja, balai kota, gedung pengadilan, sel penjara, bangunan perkantoran, bengkel kerja, menara jaga, dapur, dan tempat tinggal perwira, kepala perdagangan, dokter, pastor, pelaut, pemegang buku, serta tukang kayu. Di luar tembok benteng yang menghadap ke laut masih terdapat sejumlah bangunan penunjang yang terdiri atas tempat penjagaan pasukan artileri, tempat kereta meriam, tempat batu bara, pandai besi, tempat membuat kapal, gudang batu kapur, dan pemakaman.

Wall (1942) menyebutkan bahwa gudang-gudang logistik di benteng ini didirikan pada tahun 1686, gudang mesiu pada tahun 1720 , gudang senjata dan gereja pada tahun 1770-an, dan menara jaga bertingkat pada tahun 1791. Sementara itu, bangunan gereja pernah direstorasi pada tahun 1927 (Gambar 2). 
Dikemukakan pula bahwa bangunan-bangunan yang digunakan sebagai tempat tinggal di dalam benteng ini dibuat berlantai dua (Gambar 3).

Hal ini sesuai dengan data yang diperoleh dari catatan sejarah yang menyebutkan adanya beberapa kali penambahan dan perbaikan bangunan-bangunan di Benteng Rotterdam (Andaya, 1981).

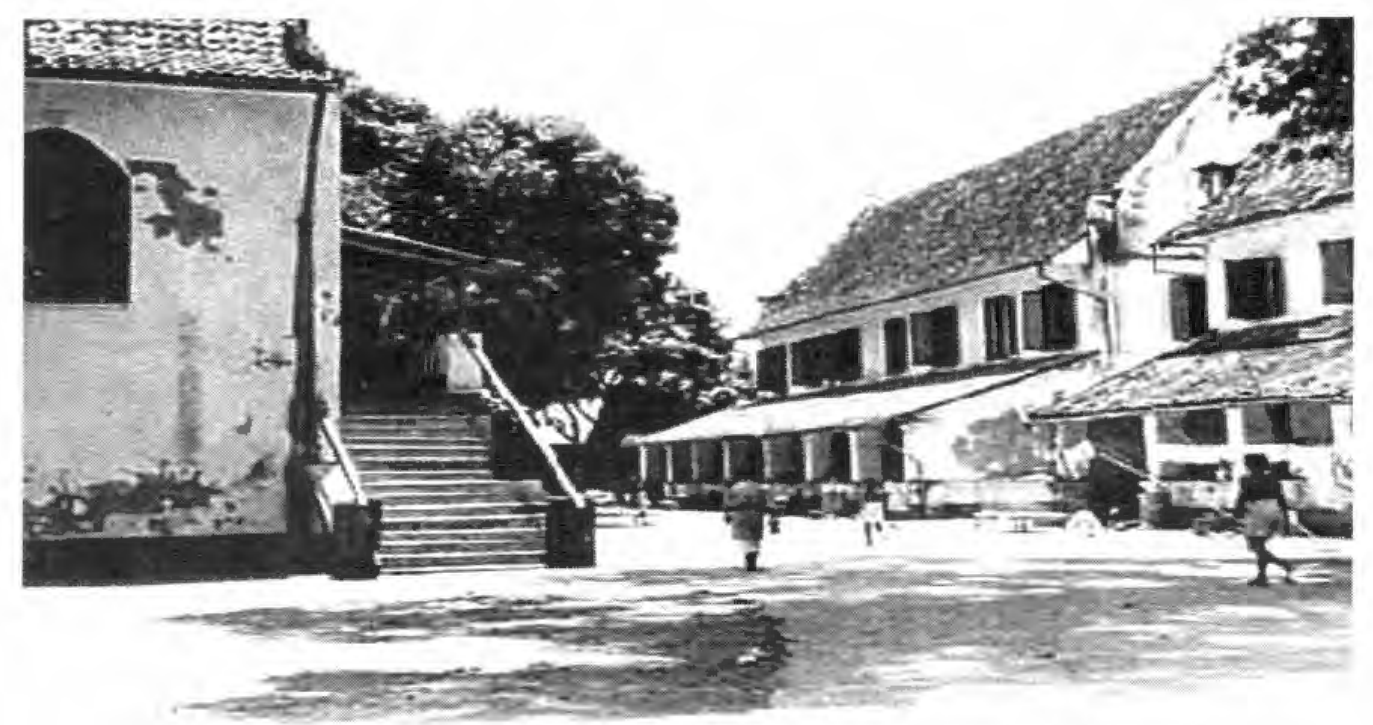

Gambar 3. Gereja (Kiri) dan bangunan tempat tinggal (Sumber: Atlas Mutual Heritage)

\section{Nilai Penting Benteng Rotterdam sebagai Kajian IImu Arkeologi dalam Mengungkapkan Kehidupan di Masa Lalu}

Banyak benteng Belanda di berbagai tempat di Indonesia yang sudah tidak terlacak lagi data fisiknya. Sebagian besar benteng-benteng dari periode awal telah diruntuhkan oleh Belanda sendiri, dan setelah kemerdekaan Indonesia tidak sedikit benteng-benteng yang tersisa juga diruntuhkan untuk kepentingan pembangunan. Secara akademik, benteng-benteng itu merupakan sumber daya budaya yang penting, baik bagi kajian arkeologi, sejarah, maupun arsitektur. Banyak hal yang dapat dipelajari dari kehadiran benteng-benteng itu dan tinggalan terkait lainnya yang masih belum terungkap secara menyeluruh. Penting pula untuk melestarikan benteng-benteng itu, karena mereka merupakan refleksi berbagai peristiwa sejarah yang merupakan mata rantai penghubung antara masa lalu dan masa kini.

Benteng Rotterdam merupakan salah satu dari sedikit bekas benteng Belanda yang hingga kini berada dalam keadaan relatif utuh. Dari segi ukuran, benteng ini merupakan benteng yang cukup besar dan memiliki komponen yang eukup 
lengkap pada masa gunanya. Dari berbagai komponen di bagian dalam dan di luar benteng seperti tersebut di atas, tersirat bahwa aktivitas di Benteng Rotterdam pada masa gunanya tidak semata-mata berkait dengan fungsi benteng sebagai sarana pertahanan dalam artian ofensif-defensif, tetapi di dalamnya pernah terjadi pula berbagai aktivitas lain di luar kemiliteran, seperti misalnya aktivitas-aktivitas ekonomi, sosial, dan budaya.

Berbagai argumentasi dalam mengupayakan pelestarian tinggalan arkeologi militer di berbagai negara antara lain menghasilkan sejumlah pandangan sebagai berikut (Schofield, 1999: 173-186; Abbas, 2002: 98-99):

- Untuk menjaga dan memupuk rasa kesejarahan suatu bangsa.

- Untuk memberi ciri pada kota-kota atau wilayah-wilayah, sekaligus menumbuhkan rasa memiliki terhadap tempat dan komunitas yang memiliki peran penting pada masa perang.

- Peran penting dalam sejarah bangsa, misalnya perubahan karakter dalam sistem pertahanan, yang dapat dilihat dari konteks fisik dan strategi.

- Bersama dengan sumber-sumber sejarah lainnya memberi peluang bagi para arkeolog dan para (calon) pengelola untuk mengubah sesuatu yang "mati" menjadi pernyataan pengalaman yang hidup penting bagi pendidikan dan wawasan kebangsaan.

- Nilai penting ekonomi.

Menyangkut tinggalan arkeologis berupa Benteng Rotterdam di Makassar, masih banyak hal yang dapat diungkapkan dari benteng ini melalui kajian arkeologi yang spesifik dengan bantuan dari sumber-sumber sejarah Makassar. Kajian arkeologis yang dapat dilakukan atas tinggalan benteng Rotterdam ini di antaranya adalah gaya seni bangun benteng yang digunakan pada masa itu (abad XVII) di Sulawesi, khususnya Sulawesi Selatan, dan jenis aktivitas apa saja yang pernah terjadi di dalam benteng pada masa gunanya. Dengan demikian, diharapkan dapat diperoleh data yang holistik mengenai seluk beluk benteng Rotterdam agar selanjutnya dapat dimanfaatkan dalam upaya pelestariannya.

\section{ACUAN}

Abbas, Novida. 2001. Dutch Forts of Java: A Locational Study. Tesis. National University Of Singapore.

Abbas, N. (2002). Bekas Benteng-Benteng Belanda Di Jawa: Penggunaan Dan "Penyalahgunaannya". Berkala Arkeologi, 22(1), 96-105.

https://doi.org/10.30883/jba.v22i1.853 
Andaya, Leonard Y. 1981. The Heritage of Arung Palakka - A History of South Sulawesi (Celebes) in the Seventeenth Century. V.K.I. 91. The Hague. Martinus Nijhoff.

Encyelopaedie van Nederlandsch-Indie 2de deel. 1918. 's-Gravenhage/Leiden. M. Nijhoff/N.V. V/H. E.J. Brill.

Hatmosuprobo, Suhardjo. 1979. Kota Yogyakarta dan Benteng Vredeburg (tidak diterbitkan). Yogyakarta. Lembaga Studi Pedesaan dan Kawasan Universitas Gadjah Mada.

Hogg, Ian V. 1975. Fortress. A History of Military Defence. London. MacDonald and Jane's.

Mundarjito et al. 1978. Laporan Penelitian Arkeologi Banten. Berita Penelitian Arkeologi No. 17. Jakarta. Pusat Penelitian Arkeologi Nasional.

Sarjiyanto, nfn. (2002). Benteng Balangnipa Di Kabupaten Sinjai, Sulawesi Selatan (Pola Tata Ruang Dan Arti Penting Kedudukannya). Berkala Arkeologi, 22(1), 81-95.

https://doi.org/10.30883/jba.v22i1.852

Schofield, J. 1999. Conserving Recent Military Remains, dalam Gill Chitty \& David Baker (eds.), Managing Historic Sites and Buildings. Hlm. 173-186. London. Routledge.

Thorn, William. Reprinted in 1993. The Conquest of Java. Singapore. Periplus Editions (HK) Ltd.

Tim Ditlinbinjarah. 1982/1983. Studi Kelayakan Benteng Belgica dan Istana Mini Banda, Maluku. Jakarta. Proyek Pemugaran dan Pemeliharaan Peninggalan Sejarah dan Purbakala.

Wall, V.I. van. 1930. Inventaris van de Nederlandsche Oudheden in het Gouvernement Celebes en Onderhoorigheden. O.V. 1929. Hlm. 83-128. Weltevreden. Albrecht \& Co.

1930/1931. Nederlandsche Oudheden in Celebes. N.I.O.N. 15e jaargang. Him. 293-305. Den Haag.

. 1942. Oude Hollandsche Bouwkunst in Indonesie. Antwerpen/Utrecht.

De Sikkel/W. de Haan. 